\title{
Etudes rurales, « Le retour du marchand dans la Chine rurale » (The return of the merchant in rural China)
}

$\mathrm{n}^{\circ}$ 161-162, Paris, Editions de l'Ecole des Hautes Etudes en Sciences Sociales, janvier-juin 2002, 342 pp.

\section{Aurore Merle}

\section{(2) OpenEdition}

\section{Journals}

Édition électronique

URL : http://journals.openedition.org/chinaperspectives/655

DOI : $10.4000 /$ chinaperspectives. 655

ISSN : 1996-4617

Éditeur

Centre d'étude français sur la Chine contemporaine

Édition imprimée

Date de publication : 1 octobre 2003

ISSN : 2070-3449

\section{Référence électronique}

Aurore Merle, «Etudes rurales, « Le retour du marchand dans la Chine rurale » (The return of the

merchant in rural China) », China Perspectives [En ligne], 49 | september-october 2003, mis en ligne le

17 janvier 2007, consulté le 24 septembre 2020. URL : http://journals.openedition.org/

chinaperspectives/655; DOI : https://doi.org/10.4000/chinaperspectives.655

Ce document a été généré automatiquement le 24 septembre 2020

(c) All rights reserved 


\section{Etudes rurales, « Le retour du marchand dans la Chine rurale » (The return of the merchant in rural China)}

$n^{\circ} 161-162$, Paris, Editions de l'Ecole des Hautes Etudes en Sciences

Sociales, janvier-juin 2002, 342 pp.

\section{Aurore Merle}

1 After Disputes au village chinois ${ }^{1}$ (Disputes in the Chinese Village), Isabelle Thireau has renewed her collaboration with Chinese specialists in the social sciences in the framework of this special edition of the journal Etudes rurales. This time the object is one which has been "largely ignored by current studies": the recomposition of mercantile spaces and exchange in rural China at the end of the Maoist era. The stakes in this research are double. It is a question of observing and analysing the rapid transformations which the Chinese countryside has experienced on the economic level for two decades. But its interest lies also in contributing to the development of economic sociology, from the "living laboratory" constituted by China.

2 The first part of this edition, Baigou : une étude de cas (Baigou, a case study), devoted to the study of a specialised market in northern China, makes clear immediately the theoretical and methodological approach which guides the authors: the return of the merchant in rural China can only be understood based on the study of local configurations. The market in Baigou, which has been the field of research for a team of Chinese sociologists for almost ten years ${ }^{2}$, offers several "mysteries" which cannot be elucidated by the classical economic theories. How to explain, indeed, the emergence and economic success of this market in an isolated rural area (Shen Yuan)? Why has this economic effectiveness rested for more than a decade on the local production of a multitude of domestic workshops (Liu Shiding)? How to explain the interest of the local authorities in the development of the markets (Wang Hansheng)? If the emergence of brands is not determined by property and competition, what logic does it follow (Shen 
Yuan and Liu Shiding)? The originality of this first section is also that it submits the "case of Baigou" to the inspection of a specialist in French economic history, Jean-Yves Grenier, thus making it possible to establish parallels with the historical development of markets in France, and to extricate the specificities of the Chinese case.

In order to place these case studies in perspective, the second part, entitled Nouveaux Héritages (New Legacies) widens the geographic area. He Bochuan analyses the growth of various markets in villages on the Pearl River; she presents other forms of trade and other political contexts, while questioning the appearance of new social practices. Isabelle Thireau and Hua Linshan look at roadside businesses and the new forms of sociability which develop there. Ma Mingjie and Sun Liping analyse how the cadres of a canton forced the peasants to undertake the cultivation of a certain kind of melon. Yunxiang Yan ponders the strategies and new behaviour with regard to the birth rate in a village in Heilongjiang. The perspective is also historical, whether the relatively recent-R Bin Wong's analysis of commercial forms and practices in rural China from the eighteenth century up to the reforms-or the more distant past: Christian Lamouroux's recounting of the relations between trade and bureaucracy in Song dynasty China.

Lastly, References, the third part, provides a more reflective point of view and sheds a different light on the research presented here. Reprinting the founding text by William Skinner which presents the model of the macro-regions, and then retracing, as Christian Lamouroux does, the peregrinations of this model, is a calling into question of the paradigm ${ }^{3}$ which has dominated the economic history of China for almost thirty years.

5 This special edition is characterised by the plurality of its investigations, approaches and objects, and the authors state that it is a question of "opening up a field rather than of defining a common position or offering general conclusions". However, several theoretical and methodological directions emerge from this work and deserve our attention.

6 First of all, by choosing the village as the scale of observation, the authors make clear their refusal to apprehend the reorganisation of market spaces and exchanges on the scale of the nation or of the macro-regions, and open up the road to a local approach to economic dynamics. As in the example of Baigou, it is not a question of isolating the village, but rather of taking it as the point of reference for discovering how trade networks are set up and extended, networks which can go beyond the regional or even the national framework.

7 The significance of this approach lies in rejecting any form of determinism and in placing the initiatives of the social actors at the heart of the analysis. These initiatives cannot be apprehended on the basis of the logic of economic rationality alone. Using qualitative methodology, the various authors shed light on the principles and norms invoked by the actors in order to justify their activities, and show that the economy is never separate from the whole of social activities and customs. It is because they are deemed acceptable in the eyes of the actors and other members of society that these activities become possible. Thus the development of the Chinese countryside over the last two decades cannot be understood without taking into account the process of legitimisation of commercial activity.

8 The emphasis placed on the analysis of the interactions between the various actors who intervene in local economic configurations also contributes to a renewal of the 
problematics of state intervention in the Chinese countryside. The contrast presented by the case of Baigou and that of the canton of $\mathrm{Yan}^{4}$ shows that relations between the local administration and the social actors cannot be defined a priori, but must be grasped in context and in a dynamic fashion. The link between national policies and local interests is then apprehended through an analysis of the local mechanisms for interpreting and reappropriating public plans of action.

But the value of this research does not lie only in a better understanding of the recent economic transformations which have affected the Chinese countryside. The authors' concern not to enclose the study of contemporary Chinese rural economics in a culturalist framework, but on the contrary to compare their observations with classical economic theories as well as with the models of the new economic sociology, makes it possible to question the bases of these models, to point out their limitations, and to bring to bear new information which is likely to contribute to a redefinition of the debate-as well as new directions for research-in economic sociology.

\section{NOTES}

1. Thireau Isabelle, Wang Hansheng éds., Disputes au village chinois. Formes du juste et recompositions locales des espaces normatifs, Paris, Editions de la Maison des Sciences de l'Homme, 2001, $342 \mathrm{p}$.

2. None of the research on Baigou presented in this issue has yet been published in China. Other research on Baigou, in particular a sociological intervention project, is currently being carried out by sociologists from the University of Qinghua.

3. By separating the administrative and economic hierarchies and integrating the social sciences into the field of Chinese studies, the macro-regions model broke with a classical approach to economic and social organisation in China, centred on the nation, and paved the way to a decentralised regional history.

4. In the case of Baigou, it was the traditional merchants and the peasants who, from the end of the 1970s, began to sell their products illicitly, the local cadres being opposed to these forms of « capitalist drift». Shen Yuan recalls their « guerilla strategy » to escape the control of the cadres. Conversely, in the canton of Yan, it was the cadres who initiated the development of the cultivation of a variety of melon, and reactivated the old political apparatus of social mobilisation in order to « force the peasants to enrich themselves » and thus increase the financial resources of the canton. 